\title{
Interactions between mediterranean shrub species eight years after experimental fire
}

\author{
Elena Marcos ${ }^{1, *}$, Reyes Tárrega ${ }^{2}$ and Estanislao Luis-calabuig ${ }^{2}$ \\ ${ }^{1}$ Area de Ecología, Escuela Técnica y Superior de Ingeniería Agraria, Campus de Ponferrada, Universidad de \\ León, Spain; ${ }^{2}$ Area de Ecología, Facultad de Ciencias Biológicas y Ambientales, Universidad de León, Spain; \\ *Author for correspondence (e-mail: degemp@unileon.es; fax: 987 291501)
}

Received 15 October 2002; accepted in revised form 7 March 2003

Key words: Competition, Cytisus spp. Erica australis, Fire, Mediterranean shrublands

\begin{abstract}
This paper is part of a wider study in which different combinations of species were assayed for the revegetation of experimentally burnt heathlands. In this particular case, we determined whether there was any interaction between the dominant species, Erica australis, which recovered by vegetative resprouting, and the only successful woody species sown, Cytisus sp., eight years after fire and seven years after sowing. A detailed study was carried out on each square metre of cover and height of both species in three $160 \mathrm{~m}^{2}$ plots. Total cover exceeded $100 \%$ in all subplots sown with Cytisus, whereas it did not reach $65 \%$ in the others, when both species coexist together. There was an inverse correlation between the covers of both species and a positive correlation between the height of Erica australis and the cover and the height of Cytisus. There was no significant difference in Erica cover in plots sown with Cytisus and plots not sown. There could be some competition for light, but both species are capable of coexisting with high canopy overlap, for at least some time. Cytisus is expanding from the seeded subplots, suggesting that the dense cover of Erica australis does not impede the establishment of Cytisus.
\end{abstract}

\section{Introduction}

Species that are typical of communities with frequent disturbances, as occurs in most Mediterranean ecosystems, regenerate by resprouting or from the soil seed bank (Naveh 1974; Keeley and Zedler 1978; Keeley 1986, 1992a, 1992b; Trabaud 1987). It is generally assumed that vegetative regeneration is an advantage in competition amongst species (Hanes 1981; Trabaud 1984, 1987; Bond and van Wilgen 1996; Pugnaire et al. 2000), since resprouters have a welldeveloped root system and only need to regenerate their aboveground parts. This advantage would make them successful in competition for light, nutrients and above and underground space, although it is more difficult for them to colonise new microsites. However, Kummerow et al. (1985) found that removal of Adenostoma fasciculatum sprouts in Southern California chaparral did not increase survival of the seeder Ceanothus greggii six months after fire.
In most of the Mediterranean basin, shrub communities have spread considerably due to ancient degradation of the forest and abandonment of pastures and cultivated fields. The result has been an increase in the risk of fires and loss of late-successional vegetation (Moreno et al. 1998; Luis-Calabuig et al. 2000; Reyes et al. 2000). Post-fire recovery in shrublands is usually quite rapid because of vegetative regrowth. However, repeated burning slows succession in these secondary stages and stops progression towards mature stages of forest (Quercus pyrenaica forest in the study area).

It has been pointed out that the effect of competition is minimal after a disturbance like fire, even though the same species compete when they have recovered to a certain size (Vilà and Terradas 1995). Generally, the problem of competition amongst species has been relatively neglected in fire-prone communities, even though it is of crucial importance for understanding function in these communities and for 
managing biodiversity (Bond and van Wilgen 1996). Although competition may also occur after fire, it is not clear if it is less intense than in mature stands (Vilà and Sardans 1999).

This paper is part of a wider study in which different combinations of herbaceous and woody species were assayed for the revegetation of experimentally burnt heathlands. Our aim was to find the most suitable combination of species to slow erosion on a short-term basis and favour succession towards forest over the long term (Fernandez-Abascal et al. 1998). Of the assayed species, only the shrub Cytisus sp. established well, and in a few years became dominant in the plots where it was sown. Our aim is to determine whether there is competition between the dominant species, Erica australis, which recovers by vegetative resprouting, and the only successful species sown, Cytisus sp. eight years after fire and seven years after sowing. Both species are highly branched evergreen shrubs (Tutin et al. 1964-1980) so competition, at least for space, would be expected.

In previous studies analyses have been carried on out the dynamics of growth in both species during the first years (Fernandez-Abascal et al. 1998; Marcos et al. 1999). Erica australis is characterised by its active resprouting capacity, which initially gives it an advantage in occupying space due to its well-developed root system, whilst other woody species had to start growing from seeds.

\section{Material and methods}

The study was conducted in an Erica australis shrub area in the province of León (NW Spain), M.T.U. coordinates: 30TUN282277. The slope is $10 \%$, orientation N-NE and elevation $1063 \mathrm{~m}$ above sea level. The climate is subhumid Mediterranean, with a dry period in summer. Late succession vegetation should be Quercus pyrenaica forest, but most of the area is heathland, as a result of pasture being deserted in the 1960s with human migration from rural areas. The mean aboveground biomass was about $1700 \mathrm{~g} / \mathrm{m}^{2}$, with most of this biomass $\left(1000 \mathrm{~g} / \mathrm{m}^{2}\right)$ contributed by Erica australis (Fernandez-Abascal et al. 2002), with a mean cover $50 \%$ and a mean maximum height of 1 $\mathrm{m}$.

Three $16 \times 10 \mathrm{~m}$ plots were burned in July 1993 and revegetated in March 1994, using different species combinations, all of them natural to the area. Fifteen permanent subplots measuring $4 \mathrm{~m}^{2}$ were es- tablished in each plot ( 4 treatments and a control replicated three times). These subplots were distributed according to the scheme in Figure 2. Treatments were randomly assigned to subplots. Seed quantity was estimated by weight in order to have 20,000 seeds, equally divided amongst the species assigned to each treatment, per square meter in each subplot sown.

1. Sowing of herbs (subplots $\mathrm{H}$ ): Lotus corniculatus (40 g), Agrostis capillaris (2.4 g) and Festuca rubra (34 g).

2. Sowing of herbs and shrubs (subplots HS): Lotus corniculatus (20 g), Agrostis capillaris (1.2 g), Festuca rubra (16 g), Cytisus sp. (10 g), Calluna vulgaris $(7 \mathrm{~g})$ and Erica australis $(24 \mathrm{~g})$.

3. Sowing of herbs and plantation of oaks (subplots HO): Lotus corniculatus (20 g), Agrostis capillaris (1.2 g), Festuca rubra (16 g) and Quercus pyrenaica (4 oak seedlings, 2 months old).

4. Sowing of herbs and shrubs and plantation of oaks (subplots HSO): Lotus corniculatus (20 g), Agrostis capillaris (1.2 g), Festuca rubra (16 g), Cytisus sp. (10 g), Calluna vulgaris (7 g), Erica australis (24 g) and Quercus pyrenaica (4 oak seedlings, 2 months old).

5. Unsown control subplots with natural post-fire regeneration (subplots C).

A combination of Cytisus scoparius and C. striatus was used. Both species coexist in these areas, though they were not found in plot sampling conducted before the experimental fire. In the case of shrub and herb species, sowing was by scattering the seed (Fernandez-Abascal et al. 1998).

Initial results are reported elsewhere (FernandezAbascal et al. 1998; Marcos et al. 1999). In July 2001 we measured the cover and maximum height of both species in each one of the $160 \mathrm{~m}^{2}$ of each plot.

Data were examined with analysis of variance to test for differences in the cover and height of Erica australis between subplots sown with Cytisus and subplots that had not been sown. Data were examined for normality and homocedasticity test (David et al. 1954; Cochan 1941). Regression analysis tested whether the cover and height of Cytisus varied with the cover and height of Erica australis. In this case data from quadrats in which either of the species did not appear were not taken into consideration. 

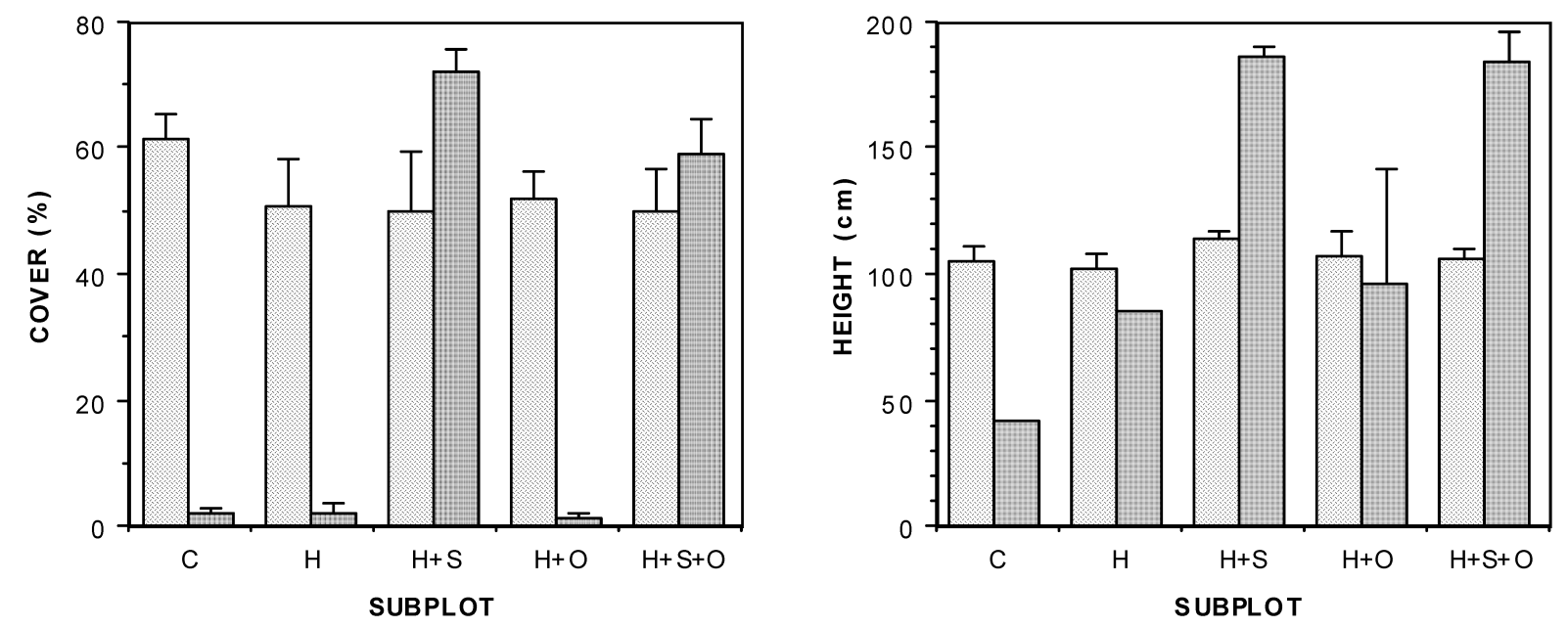

Erica australis

Cyt isus sp.

Figure 1. Mean and standard error of Erica australis and Cytisus spp. cover and height in the subplots of the three plots, eight years after experimental burning and seven years after sowing.

\section{Results}

Erica australis, the dominant species before experimental burning, recovered by vegetative resprouting and eight years later had mean covers between $50 \%$ and $62 \%$ (Figure 1). No significant differences were detected ( $\mathrm{p}=0.72$ ) when comparing Erica cover in subplots sown and unsown with Cytisus. Cytisus cover was clearly larger in the sown subplots, the average being between $59 \%$ and $72 \%$, whilst in the non sown ones it did not exceed 5\%. Total cover (both species) was $>100 \%$ in all subplots sown with Cytisus, but did not reach $65 \%$ in the others, and the differences were statistically significant $(p<0.001)$.

The mean maximum height per square metre in the sown subplots was greater in Cytisus (above $1.8 \mathrm{~m}$ ) than in Erica (with mean values between 1.0 and 1.2 $\mathrm{m})$. Again, there were no significant differences in the height of the latter species, whether the former was present or not.

Erica australis was present in all the quadrats of plot 1, in 158 of plot 2, and 136 of plot 3 (Figure 2). Cytisus colonised areas were it was not sown, but it colonised a considerably smaller area than did Erica, occupying $71 \mathrm{~m}^{2}$ in plot 1,84 in plot 2 and 69 in plot 3. The spatial distribution of Cytisus was clearly clumped, but so was that of Erica australis (significant differences from random dispersion, $\mathrm{p}<0.001$ ) in the three plots. In the $126 \mathrm{~m}^{2}$ where both species occured, total cover was $>100 \%$ in 102 quadrats and $>150 \%$ in 15 .

Regression between the covers of Erica australis and Cytisus revealed no significant tendencies when the 480 quadrats were considered $\left(160 \mathrm{~m}^{2} \times 3\right.$ plots $)$. If the quadrats in which one of the two species did not appear are excluded from these analyses, there was a highly significant negative relationship ( $\mathrm{p}<$ 0.001 ) between the species (Figure 3).

There was a significant and positive relationship between the height of the species $(\mathrm{p}<0.001)$, with Cytisus plants reaching a height $>2 \mathrm{~m}$ in 40 quadrats, and some even surpassing $3 \mathrm{~m}$. There was also a positive relationship $(\mathrm{p}<0.05)$ between the height of Erica australis and the cover of Cytisus. However, the comparison between the cover of Erica australis and the height of Cytisus shows no relationship.

\section{Discussion}

The high density of individuals in Mediterranean evergreen shrubland suggests that competition may be strong. Experiments, however, are needed to confirm this hypothesis (Vilà and Sardans 1999). Although experiment was not initially focused on competition, it plays a potential role during succession. The aim of sowing Cytisus, a leguminous shrub usually associated with better soil quality than Erica australis, was to encourage succession towards a forest community 


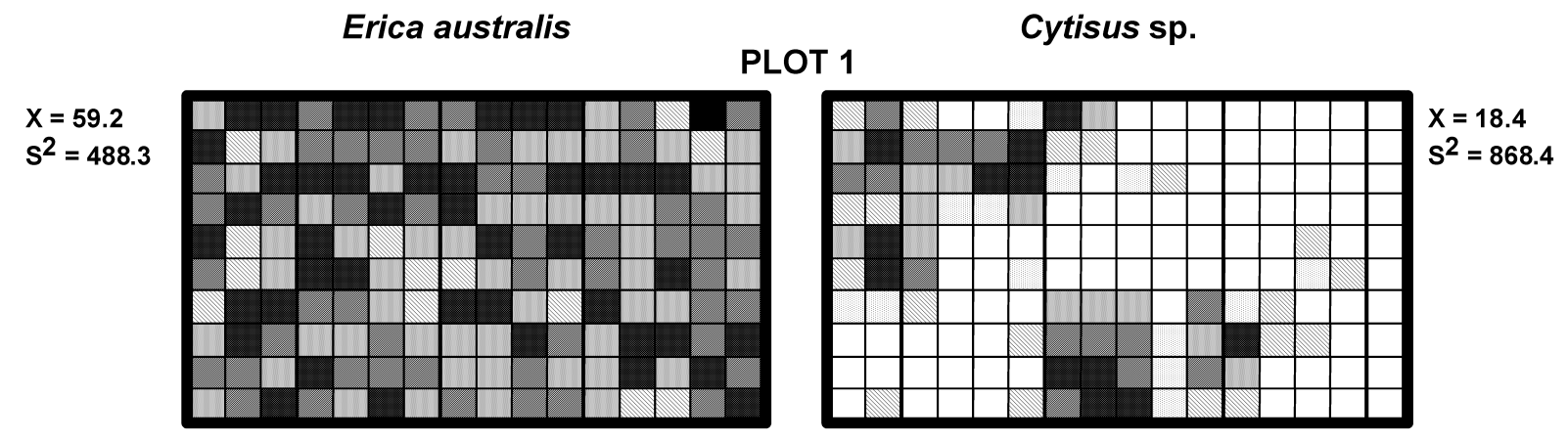

PLOT 2
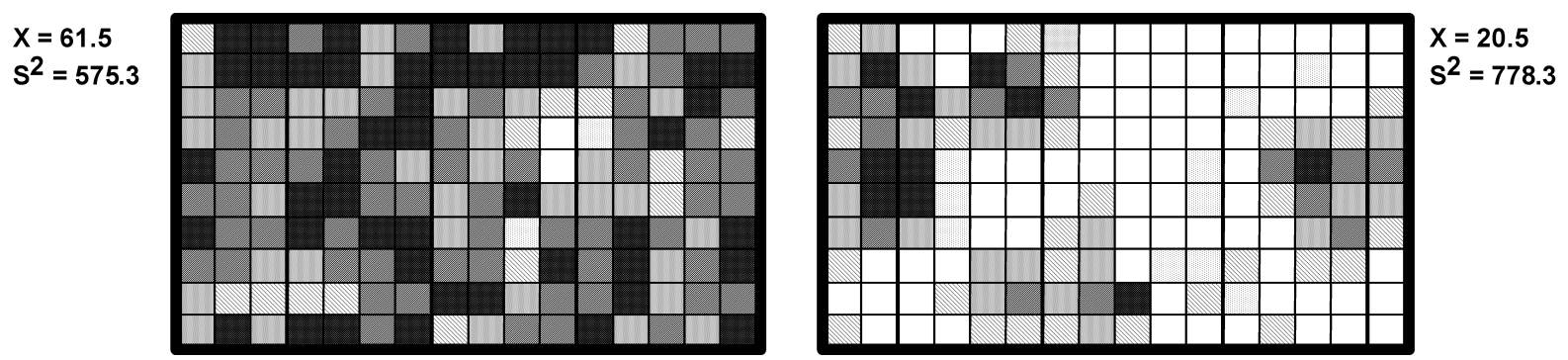

PLOT 3
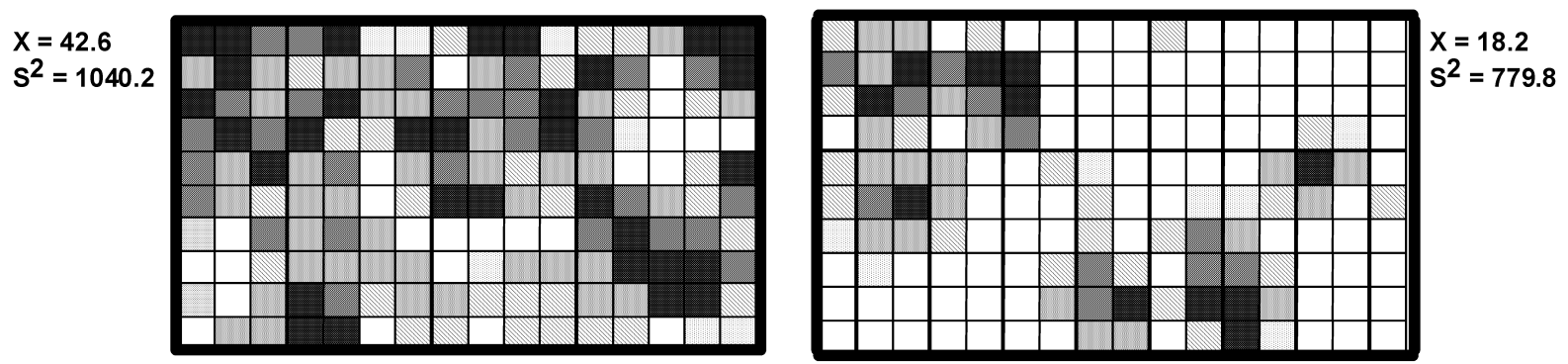

LOCATION OF SUBPLOTS

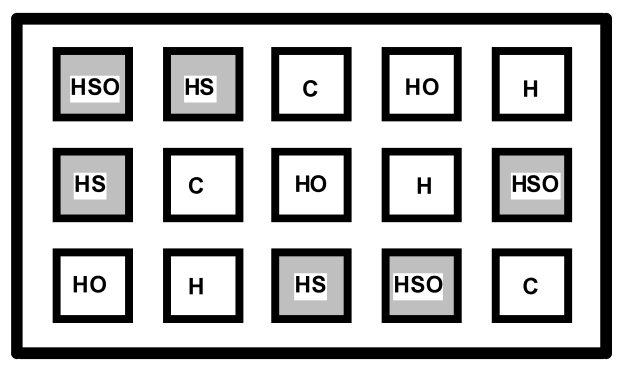

Cover (\%)

$\square<5 \%$

$\mathbb{Q} 6-25$

$\square 26-50$

$\square 51-75$

- $>75 \%$

Figure 2. Cover (\%) per square metre of Erica australis and Cytisus sp. in the sampling carried out in the summer 2001, eight years after experimental fire and seven years after sowing. Mean $(\mathrm{X})$ and variance $\left(\mathrm{S}^{2}\right)$ for each species and plot are included. A sketch of location of the subplots in each plot is also included. In plot 2, row 3, subplot $\mathrm{H}$ was replaced by subplot HSO by mistake during sowing (the order in this plot, row 3, was: $\mathrm{HO}=$ herbs + oaks, $\mathrm{HSO}=$ herbs + shrubs + oaks, $\mathrm{HS}=$ herbs + shrubs, $\mathrm{H}=$ herbs, $\mathrm{C}=$ control) 

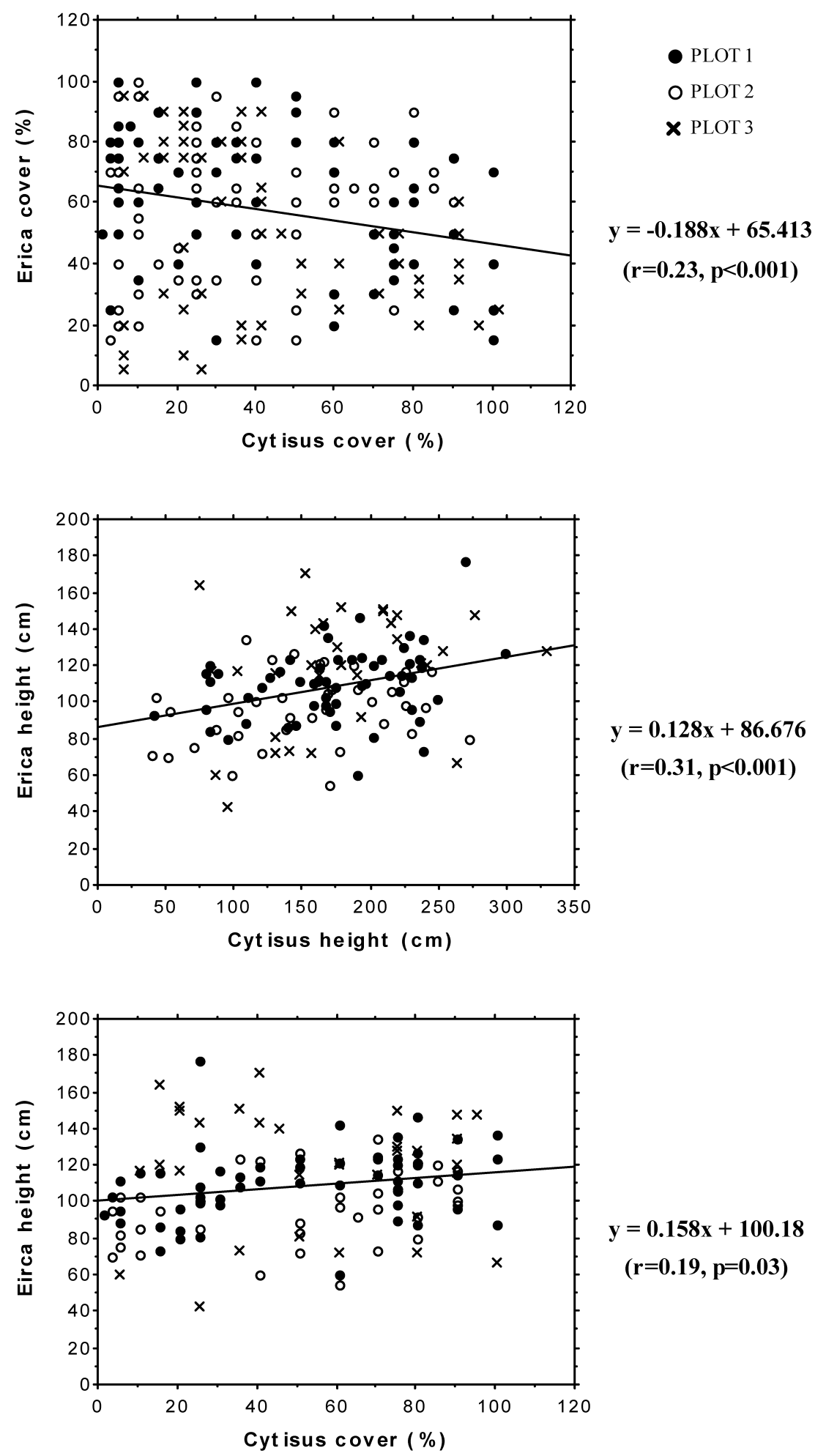

Figure 3. Regression analysis on Cytisus sp. and Erica australis cover, Cytisus sp. and Erica australis height and Cytisus sp. cover and Erica australis height. 
(Fernandez-Abascal et al. 1998; Marcos et al. 1999). We expected that Erica australis, if not eliminated, might be displaced as dominant species over time.

After fire, Cytisus spp. can recover by both vegetative resprouting and seeds (Fernández-Santos and Gómez-Gutierrez 1994; Fernández-Santos et al. 1999) that are stimulated by higher temperatures during fire (Tárrega et al. 1992; Reyes and Boedo 2001). Isolated plants of this species appear in stretches of Quercus pyrenaica forest, close to the study area, but not in the stretches of unburnt heathlands or in those subjected to burning by shepherds. This is clearly due to the fact that there is no seed bank on the soil (Valbuena et al. 2000) since Cytisus seeds sown after experimental fire grew well, though somewhat slower than the natural recovery of Erica australis by resprouting (Marcos et al. 1999). Cytisus is therefore capable of germinating and growing despite the initial advantage of the resprouter (Erica australis). Cytisus spp. are typical of the understorey, and therefore have no problem germinating in the shade, which also could favour their growth. Reyes et al. (2000) found that Cytisus striatus has greater germination rates in the dark than with photoperiod.

Eight years after fire, Erica australis cover and height had recovered, coinciding with results obtained by Calvo et al. (2002). Cytisus, which behaves like a seeder, had $<5 \%$ cover during the first year, but reached a mean of $70 \%$ in the fourth year (Marcos et al. 1999), a similar value to that found after seven years. Initial rapid growth slowed, perhaps as a result of competition. Vilà and Sardans (1999) state that there is less competition after a fire because plant density decreases and more resources are available; as succession advances and the individuals increase in size, there is greater competition amongst plants. Fernández-Santos and Gómez-Gutierrez (1994) reported intraspecific competition in Cytisus balansae, with a decrease in population density between the fourth and sixth year after fire.

In the studied area, plants of both species have grown sufficiently for interaction to occur, though it is not very apparent. The cover of Cytisus is the same as or greater than Erica australis in the sown subplots. There are no obvious differences in the cover of the latter species in the subplots despite the fact that in some quadrats with high density of both species overall covers surpassed $150 \%$. This overlap of species aboveground probably also occurs belowground (Casper and Jackson 1997) because the roots are very branched and with lignotubers to enable re- sprouting (Fernández-Santos and Gómez-Gutierrez 1994; Fernández-Santos et al. 1999; Moreno et al. 1999; Cruz and Moreno 2001).

Also, the spatial occupation by Cytisus of each plot is far from complete, though its expansion around the seeded subplots can be seen. This is probably explained by vegetative growth and seeds dispersal by autochory, causing new stems or seedlings to appear near the parent plant. In 1999 Cytisus occupied $75 \mathrm{~m}^{2}$ in plot 2 (Marcos et al. 1999), but $84 \mathrm{~m}^{2}$ in 2001, suggesting that the dense cover of Erica australis does not impede the establishment of Cytisus.

Although it is not possible to detect the effect of Cytisus on the height and cover characteristics of Erica australis when comparing the sown and unsown subplots by analysis of variance, regression analysis revealed an inverse correlation between the cover of the species. On the other hand, the direct correlation between the height of the two species could indicate possible competition for light (Pugnaire et al. 2000). Also, the greater the cover of Cytisus the higher Erica australis grows. Greater growth in Cytisus could favour an increase in the height of Erica at the expense of a reduction in its cover whilst trying to avoid the shade.

In the studies carried out on fire-prone communities, there has been a tendency to ignore interactions between species because they were believed irrelevant in predicting successional change (Bond and van Wilgen 1996). Frequent disturbances, which periodically cause a reduction in phytomass and subsequent competition, would allow species coexistence. However, it is not clear whether competitive exclusion and progress towards a more mature stage would occur in the absence of these disturbances. Keeley (1992a, $1992 b$ ), in a study on chaparral sites unburned for 120 years, found a vigorous shrub population and although colonisation by tree seedlings could be observed, successional replacement of the chaparral was not imminent.

In our study, the species are capable of coexisting with high canopy overlap, for at least some time. Further, the colonisation of new microsites by Cytisus shows that there is a tendency for shrub overlap to increase. 


\section{References}

Bond W.J. and van Wilgen B.W. 1996. Fire and Plants. Chapman \& Hall, New York.

Calvo L., Tárrega R. and Luis E. 2002. The dynamics of mediterranean shrub species over 12 years following perturbations. Plant Ecology 160: 25-42.

Casper B.B. and Jackson R.B. 1997. Plant competition underground. Annual Review of Ecology and Systematics 28: 545570.

Cochan W.G. 1941. The distribution of the largest of a set estimated variances as a fraction of their total. Ann. Eugen (Lond.) 11: $47-61$.

Cruz A. and Moreno J.M. 2001. Lignotuber size of Erica australis and its relationships with soil resources. Journal of Vegetation Science 12: 373-384.

David et al. 1954. The distribution of the ratio, in a single normal sample of range to standard deviation. Biometrika 41: 482-493.

Fernandez-Abascal I., Luis E., Tárrega R. and Valbuena L. 1998. Five years of recovery after experimental fire in a heathland. Effects of sowing native species. In: Viegas E.X. (ed.), Proc. 3rd International Conference on Forest Fire Research. Coimbra, Portugal, pp. 1889-1899.

Fernandez-Abascal I., Luis E., Tárrega R. and Marcos E. 2002. Trends in post-fire biomass recovery in an Erica australis heathland. In: Trabaud L. and Prodon P. (eds), Bachuys Publishers, Leiden, pp. 33-42.

Fernández-Santos B. and Gómez-Gutierrez J.M. 1994. Changes in Cytisus balansae populations after fire. Journal of Vegetation Science 5: 463-472.

Fernández-Santos B., Gómez-Gutierrez J.M. and Moreno-Marcos G. 1999. Effects of disturbance caused by traditional Spanish rural land use on the regeneration of Cytisus multiflorus. Applied Vegetation Science 2: 239-250.

Hanes T. 1981. California chaparral. In: DiCastri F., Goodall D. and Specht R. (eds), Ecosystems of the World, Mediterranean-Type Shrublands. Vol. 11. Elsevier, Amsterdam, pp. 139-174.

Keeley J.E. 1986. Resilience of mediterranean shrub communities to fire. In: Dell B., Hopkins A.J.M. and Lamont B.B. (eds), Resilience in Mediterranean-Type Ecosystems. Dr. W. Junk Publishers, Dordrecht, pp. 95-112.

Keeley J.E. 1992a. Recruitment of seedlings and vegetative sprouts in unburned chaparral. Ecology 73: 1194-1208.

Keeley J.E. 1992b. Demographic structure of California chaparral in the long-term absence of fire. Journal of Vegetation Science 3: 79-90.

Keeley J.E. and Zedler P.H. 1978. Reproduction of chaparral shrubs after fire: a comparison of sprouting and seeding strategies. The American Midland Naturalist 99: 142-161.

Kummerow J., Ellis B.A. and Mills J.N. 1985. Post-fire establishement of Adenostoma fasciculatum and Ceanothus greggii in southern California chaparral. Madroño 32: 148-157.

Luis-Calabuig E., Tárrega R., Calvo L., Marcos E. and Valbuena L. 2000. History of landscape changes in northwest Spain according to land use and management. In: Trabaud L. (ed.), Life and Environment in the Mediterranean. Wit press, Southampton, pp. 43-86.
Marcos E., Fernández-Abascal I., Tárrega R. and Luis-Calabuig E. 1999. Temporal evaluation of the population of Cytisus spp. used as a recovery element in a burned area. In: Int. Symposium on Forest Fires: Needs \& Innovations. Athens, pp. 395399.

Moreno J.M., Vazquez A. and Velez R. 1998. Recent history of forest fires in Spain. In: Moreno J.M. (ed.), Large Forest Fires. Backhuys Publishers, Leiden, pp. 159-185.

Moreno J.M., Cruz A. and Oechel C. 1999. Allometric relationships in two lignotuberous species from Mediterranean-type climate areas of Spain and California. Journal of Mediterranean Ecology 1: 49-60.

Naveh Z. 1974. Effects of fire in the Mediterranean Region. In: Kozlowski T.T. and Ahlgren C.E. (eds), Fire and Ecosystems. Academic Press, New York, pp. 401-434.

Pugnaire F.I., Armas C. and Tirado R. 2000. Balance de las interacciones entre plantas en ambientes mediterráneos. In: Zamora R. and Pugnaire F.I. (eds), Ecosistemas Mediterráneos. Análisis Funcional. C.S.I.C. and A.E.E.T. Textos Universitarios.

Reyes O., Basanta M., Casal M. and Diaz-Vizcaino E. 2000. Functioning and dynamics of woody plant ecosystems in Galicia (NW Spain). In: Trabaud L. (ed.), Life and Environment in the Mediterranean. Wit press, Southampton, pp. 1-39.

Reyes O. and Boedo M. 2001. El fuego como controlador de la germinación de Cytisus striatus y de C. multiflorus y su aplicación agronómica. In: III Congreso Forestal Español. Montes para la Sociedad del Nuevo Milenio. Granada, Tomo IV, pp. $15-21$.

Tárrega R., Calvo L. and Trabaud L. 1992. Effects of high temperatures on seed germination of two woody Leguminosae. Vegetatio. 102: 139-147.

Trabaud L. 1984. Fire adaptation strategies of plants in the French Mediterranean area. In: Margaris N.S., Arianoustou-Farragitaki M. and Oechel W.C. (eds), Being Alive on Land. Tasks for Vegetation Science. Dr. W. Junk Publishers, The Hague, pp. 63-69.

Trabaud L. 1987. Natural and prescribed fire: survival strategies of plants and equilibrium in mediterranean ecosystems. In: Tenhunen J.D. (ed.), Plant Response to Stress. Springer-Verlag, Berlin, pp. 607-621.

Tutin T.G., Heywood V.H., Burges N.A., Valentine D.H., Moore D.M. and Walters S.M. et al. 1964-1980. Flora Europaea. Cambridge University Press.

Valbuena L., Tárrega R. and Luis-Calabuig E. 2000. Seed banks of Erica australis and Calluna vulgaris in a heahtland subjected to experimental fire. Journal of Vegetation Science 11: 161166.

Vilà M. and Terradas J. 1995. Effects of competition and disturbance on the resprouting performance of the Mediterranean shrub Erica multiflora L. (Ericaceae). American Journal of Botany $82: 1242-1248$.

Vilà M. and Sardans J. 1999. Plant competition in mediterraneantype vegetation. Journal of Vegetation Science 10: 281-294. 